\title{
Relationship Between Squamous Cell Carcinoma of the Anterior Two Thirds of the Tongue and Removable Denture Use - A Pioneer Study in a Portuguese Population
}

\author{
Rui ALBUQUERQUE ${ }^{1}$ \\ Jose LÓPEZ-LÓPEZ ${ }^{1}$ \\ Antonio MARÍ-ROIG ${ }^{2}$ \\ Enrique JANÉ-SALAS ${ }^{1}$ \\ Eduardo CHIMENOS-KÜSTNER ${ }^{1}$ \\ Jorge Rosa SANTOS ${ }^{3}$ \\ ${ }^{1}$ Odontotostomatology Department, Dental School, University of Barcelona, Catalonia, Spain \\ ${ }^{2}$ Hospital Universitario Bellvitge, University of Barcelona, Catolonia, Spain \\ ${ }^{3}$ Head and Neck Surgery Department, Instituto Português de Oncologia de Lisboa Francisco Gentil, Lisbon, Portugal

\begin{abstract}
The aim of the study was to determine whether there is any relationship between the presence of removable dentures and squamous cell carcinoma of the anterior two thirds of the tongue in a Portuguese population. A retrospective cross-sectional study was conducted on patients with a biopsy-proven diagnosis of squamous cell carcinoma of the tongue, who were seen and treated at the Department of Head and Neck Surgery of the Portuguese Institute of Oncology 'Francisco Gentil', Lisbon, Portugal, during a 3-year period. Several factors were examined: gender, use of removable dentures, age, location of the lesion, and alcohol and tobacco consumption. One hundred and six cases were selected from the initial 151 cases, with a male:female ratio of 3:1 and the lateral borders being the most commonly affected site. The prevalence in both genders was between the sixth and seventh decade of life. Men were more likely to consume alcohol and tobacco than women, and no relationship was observed between denture use and presence of carcinoma of the tongue. In light of the data obtained, it may be considered that female use of a denture plays an important role, but it cannot be identified as a remarkable etiologic factor.
\end{abstract}

Key Words: squamous carcinoma, tongue, denture.

\section{INTRODUCTION}

Oral squamous cell carcinoma (OSCC) is defined as a malignant neoplasm deriving from the stratified squamous epithelium. It is the most common malignant neoplasm of the oral cavity, accounting to roughly $95 \%$ of all oral cancers, and clinically shows a local, regional, and systemic progression capacity $(1,2)$.

OSCC of the tongue is clearly more prevalent in people who are between 60 and 80 years of age, although sometimes lesions may be detected in very young people $(3,4)$. In the USA and Europe, the incidence rates of OSCC of the tongue among young adults are rising. It used to be estimated that about $3 \%$ of these carcinomas occur in young patients, but an increase to $6-7 \%$ has been recently recognized (5-8). In this subgroup, the proportion of women is greater than in general population of tongue malignancies and history of smoking and drinking is less frequently reported (3-6). Because tongue cancer is uncommon before the age of 45 , little is known about the risk profile and treatment outcome in younger patients (2-8).

Studies with European populations, more specifically from England and Wales $(2,9)$ found that over $30 \%$ of intraoral cancers were lingual, which was similar to the value found in Torino, Italy $(32.6 \%)(2,10)$. France reported the highest incidence rates for male tongue cancer in Europe $(2,11)$, which is probably related 
to the high alcohol consumption (2). In fact, an increase in tongue cancer has been reported in several European female populations including Scotland (2,12), England and Wales $(2,9)$, Sweden $(2,13)$ and Denmark $(2,14)$.

Since there is no single cause of tongue cancer, several factors are implicated in the etiology, including tobacco (smoked or chewed), consumption of alcohol, nutritional deficiencies, immunosuppression, virus and presence of preexisting diseases and factors like dental trauma $(9,15,16)$. Of them all, tobacco and alcohol are currently considered the two most important factors for the development of this type of carcinoma (9-12). However, new research into the molecular biology of oral cancer has also pointed to the possibility of predisposing genetic factors being significant $(17,18)$.

Regarding to trauma, the chronic irritation caused by ill-fitted dentures, fractured restorations and other erosive factors will result in alterations of the mucosa which, together with other factors (such as alcohol and tobacco), may lead to the development of the carcinoma (8-12). Some studies record the existence of squamous carcinoma in the anterior two thirds of the tongue with a local traumatic element. While anecdotally carcinoma appears to develop in areas of the oral cavity covered by prostheses, no studies have ever been designed in a Portuguese population to investigate whether it is an etiologic factor.

The aim of this study was to determine the relationship between the use of removable dentures and the presence of squamous cell carcinoma of the anterior two thirds of the tongue in a Portuguese population.

\section{MATERIAL AND METHODS}

A retrospective cross-sectional study was carried out on patients who were seen and treated at the Department of Head and Neck of the Portuguese Institute of Oncology 'Francisco Gentil', Lisbon, Portugal during a 3-year period.

Inclusion criteria used were: patients of any age and gender, squamous carcinoma anatomopathologically diagnosed and located in the anterior two thirds of the tongue, alcohol and tobacco consumption and removable denture use. Exclusion criteria were: patient whose clinical history did not contain any data relating to variables such as alcohol or tobacco consumption, gender, primary carcinoma location, and denture use; OSCC of the mobile tongue with systemic metastasis or invasion of adjacent structures ( $\mathrm{Mx}$ and $\mathrm{T} 4 \mathrm{NxMx}$ ); patients with history of oral carcinoma; patients who previously underwent any treatment for oral carcinoma.

Upon studying the clinical histories, information was gathered on gender, age, tobacco or alcohol consumption, use of removable denture, and location of the carcinoma (lateral border, ventral or dorsal). Dentures were total and partial and were described in the clinical history as being in direct contact with the area of carcinoma.

In order to eliminate doubts about cancer location and the influence of the presence of denture, the T4 was not considered due the nature of its size and the possibility of causing doubts about the origin of the carcinoma.

With respect to tobacco, any patient who reported smoking habits (history did not have stricter quantitative data) was considered a current smoker and a former if quit smoking less than two years before. With respect to alcohol, any person who drank on a daily basis (without any distinction to the quantity) and a former if quit drinking less than two years before. In the analysis of the variables, we considered the terminology "YES" for current and former and "NO" for more recent smokers and drinkers or who quit more than two years before. Regarding to denture use, any patient with complete or partial denture, acrylic or chromium-cobalt, upper or lower was considered.

For statistical analysis, the Statistical Package for Social Sciences (SPSS) program was used, while applying the Binomial test for comparison between genders suffering OSCC of the mobile tongue and the Chi-square test for comparison between genders, depending on factors such as denture use, age and location of the carcinoma. The rejection level for the null hypothesis was less than or equal to $0.05(5 \%)$.

\section{RESULTS}

Upon applying the inclusion and exclusion criteria, 106 cases, $71 \%$ of which were men, were selected out of 151 cases of carcinoma of the tongue, on the basis of clinical history data (Table 1).

A total of $37.7 \%$ of the patients with OSCC of the anterior two thirds of the tongue used removable denture, notwithstanding the fact that the percentage is slightly higher in women $(38.7 \%)$ than in men $(37.3 \%)$. However, according to the Chi square test $(1)=0.018$, $\mathrm{p}=0.894$, the difference in proportion was not statistically relevant (Table 1). 
The arithmetic mean age of the patients with OSCC of the mobile tongue was 63.7 years, while the age segment of male and female patients with or without denture varied between 61 and 70 years of age. Upon using the Pearson's Chi square test to determine the existence of statistically relevant differences between the mean age, according to gender and denture use, we obtained a p-value of $0.220>0.050$, indicating the lack of statistically relevant differences (Fig. 1).

As much as $77.5 \%$ out of 40 patients using denture had carcinoma located on the lateral border of the tongue, while the remaining patients $(22.5 \%)$ were cases of carcinoma located elsewhere in the tongue (9.4\% ventral, 5.7\% dorsal, and $1.9 \%$ tip) (Fig. 2). Female patients showed a higher OSCC incidence in the lateral border of the tongue when using denture than male patients; however, despite the difference in proportion, there was no relationship between the use of denture and location of the carcinoma, Chi square (1)= $1.388, \mathrm{p}=0.239$. This conclusion is confirmed even when analyzing the relationship between the lateral border and non-border variable (including all locations: ventral, dorsal and tip of the tongue), depending on whether the patient was female (Chi-square $=0.247, \mathrm{p}=0.619$ ) or male (Chi-square $=1.180, \mathrm{p}=0.277$ ).

As far as alcohol or tobacco consumption and denture use are concerned, most of the male population smoked, drank and did not wear a denture (44\%), whereas

Table 1. Use of denture according to gender.

\begin{tabular}{|c|c|c|c|c|}
\hline \multirow{2}{*}{ Gender } & \multirow{2}{*}{ Data } & \multicolumn{2}{|c|}{ Denture } & \multirow{2}{*}{ Total } \\
\hline & & Yes & No & \\
\hline \multirow{4}{*}{ Female } & Frequency & 12 & 19 & 31 \\
\hline & $\%$ Gender & $38.7 \%$ & $61.3 \%$ & $100.0 \%$ \\
\hline & $\%$ Denture & $30.0 \%$ & $28.8 \%$ & $29.2 \%$ \\
\hline & $\%$ Total & $11.3 \%$ & $17.9 \%$ & $29.2 \%$ \\
\hline \multirow{4}{*}{ Male } & Frequency & 28 & 47 & 75 \\
\hline & $\%$ Gender & $37.3 \%$ & $62.7 \%$ & $100.0 \%$ \\
\hline & $\%$ Denture & $70.0 \%$ & $71.2 \%$ & $70.8 \%$ \\
\hline & $\%$ Total & $26.4 \%$ & $44.3 \%$ & $70.8 \%$ \\
\hline \multirow{3}{*}{ Total } & Frequency & 40 & 66 & 106 \\
\hline & $\%$ Gender & $37.7 \%$ & $62.3 \%$ & $100.0 \%$ \\
\hline & $\%$ Total & $37.7 \%$ & $62.3 \%$ & $100.0 \%$ \\
\hline
\end{tabular}

most of the female population did not smoke, drink or wear a denture $(51.6 \%)$.

The proportion of males who smoked and drank was notably greater $(96.3 \%)$ than that of females (3.8\%) (Table 2).

\section{DISCUSSION}

Over the past few years, there has been an increased incidence of OSCC of the tongue, whereas it has remained constant or has decreased in other topographical locations of the mouth and pharynx -particularly appearing in young patients between 20 and 44 years of age $(4-8,19)$.

In this study, OSCC incidence in the mobile tongue was $3: 1$, which is a proportion equal to that described in the literature; however, this difference tends to be reduced when the studied population is more

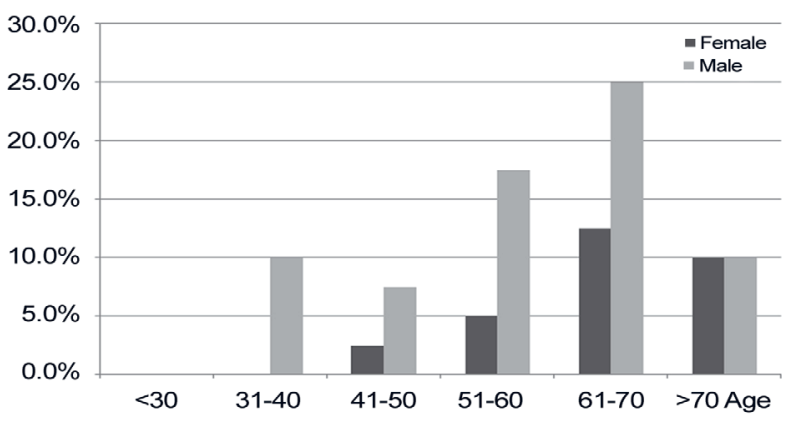

Figure 1. Age distribution regarding the use of denture.

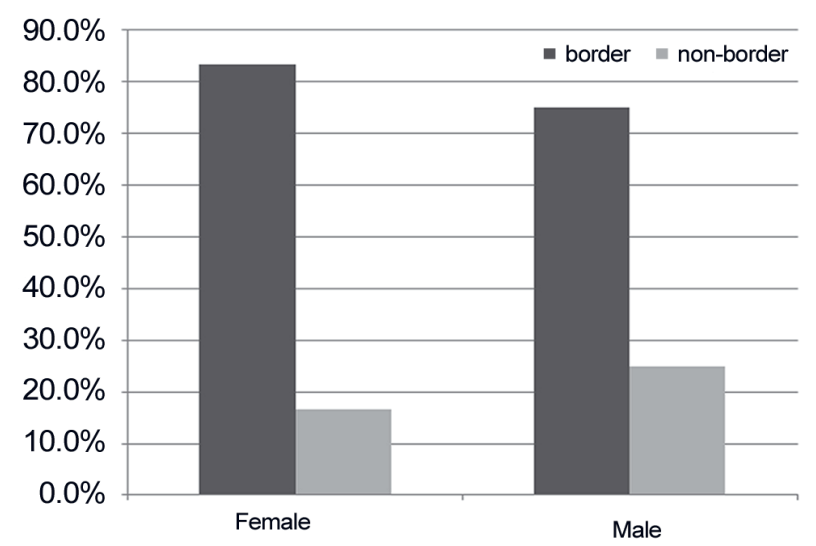

Figure 2. Gender comparison between patients with OSCC of the mobile tongue using denture, considering border and non-border locations. Non-border locations (ventral region, dorsal region and tip of the tongue). 
recent. In our series, $71 \%$ were men and this proportion is slightly greater than the proportion detected in previous studies. However, upon testing with the Binominal test, this difference was not relevant, $\mathrm{p}=0.238(1,4-6)$.

OSCC of the anterior $2 / 3$ of the tongue generally manifests during the sixth decade of life. When searching for a relationship between the use of removable denture and an increase in a certain age segment, according to the Chi square test, no association was observed with respect to the low impact that denture use had on the sample.

The influence of the denture in the development of oral carcinomas, especially those located in the tongue, has not yet been fully clarified as most studies have referred to the oral cavity, in general $(20,21)$. Trieger et al. (20) observed a significant presence of dentures in patients with oral cancer while Day et al. (21) observed that Black people who used dentures were found to have a significantly lower risk than those who never wore dentures, whereas a small excess risk was seen among Whites who wore dentures. However other studies $(22,23)$ showed that denture wearing per se did not increase oral cancer risk. In this study, which is consistent with the literature $(22,23)$, the use of denture was not relevant, although our date showed a higher prevalence among women. This observation suggests that women were probably more concerned about the appearance of their teeth and the possibility of rehabilitation with dentures. Regarding this, further studies should to be done in order to understand and compare the use of dentures in women.

Table 2. Use of denture and alcohol and tobacco consumption according to gender.

\begin{tabular}{cccc}
\hline \multicolumn{2}{c}{ Etiological factors } & Males & Females \\
(tobacco, alcohol, denture) & $\mathrm{N}(\%)$ & $\mathrm{N}(\%)$ \\
\hline $\begin{array}{c}\text { Tobacco use } \\
\text { Alcohol use }\end{array}$ & Denture & $17(22.7)$ & $1(3.2)$ \\
No denture & $33(44.0)$ & $1(3.2)$ \\
Tobacco use & Denture & $1(1.3)$ & $2(6.5)$ \\
No alcohol use & No denture & $3(4.0)$ & $0(0.0)$ \\
No tobacco use & Denture & $2(2.7)$ & $1(3.2)$ \\
Alcohol use & No denture & $6(8.0)$ & $2(6.5)$ \\
No tobacco use & Denture & $8(10.7)$ & $8(25.8)$ \\
No alcohol use & No denture & $5(6.7)$ & $16(51.6)$ \\
Total & & $75(100.0)$ & $319(100.0)$ \\
\hline
\end{tabular}

The most common location of OSCC of the tongue in males and females was the lateral border region, coinciding with that observed in several previous studies $(2,3,5)$. This area is considered within the oral cavity to be one of the high-risk anatomical areas for this type of cancer. No significant relationship between the use of denture and an increase in the incidence of locations was detected, particularly at the border level, irrespective of the fact that there was a slightly higher percentage reported on women; although insignificant, it seems to be consistent with the literature (19-21).

In regards to whether the use of alcohol and tobacco is more prevalent in males than in females, and not being related to the traumatic effect of the denture, the results of this study concurs with those of Laronde et al. (21) and Hirota et al. (22), among others, confirming the role of these two agents as the main etiologic factors in the development of OSCC of the mobile tongue. In addition, the second highest percentage was detected in the male population (22.7\%) who smokes and drinks alcohol, being more likely to suffer from denture trauma. The fact that most women consumed less alcohol and tobacco when compared to men is in accordance with several studies $(2,8,12)$. However an increase of tongue's cancer in women as been observed, specially on those less than 40 and generally with no records of alcohol and tobacco consumption $(24,25)$. As in the case of men, the second highest female percentage (no smoking or drinking and wears denture) points out that the traumatic effect of removable dentures plays a significant-though not essential-role in the development of squamous carcinoma.

In the present study, no relationship between denture use and the presence of OSCC of the tow anterior thirds tongue was observed. In light of the obtained data, it may be considered that female use of a denture plays an important role, but it cannot be identified as a remarkable etiologic factor in the onset of this type of carcinoma.

\section{RESUMO}

O objetivo deste estudo foi determinar se existe alguma relação entre o uso de prótese removível e o carcinoma escamoso dos dois terços anteriores na população portuguesa estudada. Um estudo retrospectivo foi conduzido em paciente com diagnóstico anatomopatologico de carcinoma escamoso dos dois terços anteriores, diagnosticados no Instituto Português de Oncologia, Francisco Gentil, Lisboa desde 1 de Janeiro de 2001 até 31 de Dezembro de 2003. Diferentes fatores foram analisados: o gênero, uso de prótese removível, idade, localização, álcool e tabaco. Dos 
151 casos iniciais de carcinoma, foram selecionados 106 casos mostrando numa proporção de 3:1 (masculino/feminino). Os bordos laterais foram a localização mais comum e a prevalência em ambos os sexos sitou-se entre a sexta e a sétima década. A presença deálcool e tabaco foi significativamente mais comum nos homens não se observando relação entre o uso de prótese e a presença do carcinoma na língua. Não se observou relação estatística entre o uso de prótese removível e o carcinoma escomoso dos dois terços anteriores da língua. Face aos resultados, o uso de prótese no sexo feminino desempenha um papel importante ainda que não possa ser considerado um fator etiológico significativo.

\section{REFERENCES}

1. Dantas DD, Ramos CC, Costa AL, Souza LB, Pinto LP. Clinicalpathological parameters in squamous cell carcinoma of the tongue. Braz Dent J 2003;14:22-25.

2. Moore R, Johnson W, Pierce M, Wilson F. The epidemiology of tongue cancer: a review of global incidence. Oral Dis 2000;6:7584.

3. Siegelmann-Danieli N, Hanlon A, Ridge A, Padmore R, Fein A, Langer J. Oral tongue cancer in patients less than 45 years old: institutional experience and comparison with older patients. J Clin Oncol 1998; 16:745-753.

4. Pitman T, Jonhson T, Wagner L, Myers N. Cancer of the tongue in patients less than forty. Head \& Neck 2000;22:297-302.

5. McGregor GI, Davis N, Robins RE. Squamous cell carcinoma of the tongue and lower oral cavity in patients under 40 years of age. Br J Cancer 1989;146:88-92.

6. Vargas H, Pitman KT, Johnson JT, Galati LT. More aggressive behavior of squamous cell carcinoma of the anterior tongue in young women. Laryngoscope 2000;110:1623-1626.

7. Siegelmann-Danieli N, Hanoln A, Ridge JA, Padmore R, Fein DA,Langer CJ, et al.. Oral tongue cancer in patients less than 45 years old: institutional experience and comparison with older patients. J Clin Oncol 1998;16:745-753.

8. Popovtzer A, Shpitzer T, Bahar G, Marshak G, Ulanovski D, Feinmesser R. Squamous cell carcinoma of the oral tongue in young patients. Laryngoscope 2004;114:915-917.

9. Hindle I, Nally F. Oral cancer: a comparative study between 196267 and 1980-84 in England and Wales. Br Dent J 1991;170:15-20.

10. Bachar G, Hod R, Goldstein DP, Irish JC, Gullane PJ, Brown D, et al.. Outcome of oral tongue squamous cell carcinoma in patients with and without known risk factors. Oral Oncol 2011;47:45-50.

11. Hill C, Benhamou E, Doyon F. Trends in cancer mortality, France 1950-1985. Br J Cancer 1991;63:587-590.
12. Macfarlane GJ, Boyle P, Scully C. Oral cancer in Scotland: changing incidence and mortality. BMJ 1992;305:1121-1123.

13. Ostman J, Anneroth G, Gustafsson H, Tavelin B. Malignant oral tumours in Sweden 1960-1989 - an epidemiological study. Eur J Cancer B Oral Oncology 1995;31B:106-112.

14. Moller $\mathrm{H}$. Changing incidence of cancer of the tongue, oral cavity and pharynx in Denmark. J Oral Pathol Med 1989;18:224-229.

15. Muir C, Weiland L. Upper aerodigestive tract cancers. Cancer 1995;75(Suppl):147-153.

16. Kantola S, Parikka M, Jokinen K, Hyrynkangs K, Soini Y, Alho OP, et al.. Prognostic factors in tongue cancer - relative importance of demographic, clinical and histopathological factors. Br J Cancer 2000;83:614-619.

17. Sanguansin S, Petmir S, Punyarit P, Vorasubin V, Weerapradist W, Surarit R. Exp HMSH2 gene alterations associated with recurrence of oral squamous cell carcinoma Clin Cancer Res 2006;25:251257.

18. Jin C, Jin Y, Wennerberg J, Annertz K, Enoksson J, Mertens F Cytogenetic abnormalities in 106 oral squamous cell carcinomas. Cancer Genet Cytogenet 2006;164:44-53.

19. Stanko P, Satko I, Czako L, Beno M, Danko J, Zmeko S. Squamous cell carcinoma of the oral cavity. Bratisl Lek Listy 2007;108:292 296.

20. Trieger N, Ship II, Taylor GW, Weisberger D. Cirrhosis and other predisposing factors in carcinoma of the tongue. Cancer 1958; 11:357-362.

21. Day GL, Blot WJ, Austin DF, Bernstein L, Greenberg RS, PrestonMartin S et al.. Racial differences in risk of oral and pharyngeal cancer: alcohol, tobacco and other determinants. J Natl Cancer Inst 1993;85:465-473.

22. Lissowska J, Pilarska A, Pilarski P, Samolczyk-Wanyura D, Piekarczyk J, Bardin-Mikolłajczak A,et al.. Smoking, alcohol, diet, dentition and sexual practices in the epidemiology of oral cancer in Poland.no association-oral cáncer. Eur J Cancer Prev 2003;12:25-33.

23. Zheng TZ, Boyle P, Hu HF, Duan J, Jian PJ, Ma DQ, et al.. Dentition, oral hygiene, and risk of oral cancer: a case-control study in Beijing, People's Republic of China. Cancer Causes Control 1990;1:235-241.

24. Llewellyn CD, Johnson NW, Warnakulasuriya KA. Risk factors for squamous cell carcinoma of the oral cavity in young people--a comprehensive literature review. Oral Oncol 20011;37:401-418.

25. Garavello W, Spreafico R, Gaini RM. Oral tongue cancer in young patients: a matched analysis. Oral Oncol 2007;43:894-897.

Received April 3, 2011

Accepted August 1, 2011 